\title{
MLP (muscle LIM protein) as a stress sensor in the heart
}

\author{
Byambajav Buyandelger • Keat-Eng Ng • \\ Snjezana Miocic • Izabela Piotrowska • Sylvia Gunkel • \\ Ching-Hsin Ku • Ralph Knöll
}

Received: 20 December 2010 /Revised: 11 March 2011 / Accepted: 24 March 2011 /Published online: 13 April 2011

(C) The Author(s) 2011. This article is published with open access at Springerlink.com

\begin{abstract}
Muscle LIM protein (MLP, also known as cysteine rich protein 3 (CSRP3, CRP3)) is a musclespecific-expressed LIM-only protein. It consists of 194 amino-acids and has been described initially as a factor involved in myogenesis (Arber et al. Cell 79:221-231, 1994). MLP soon became an important model for experimental cardiology when it was first demonstrated that MLP deficiency leads to myocardial hypertrophy followed by a dilated cardiomyopathy and heart failure phenotype (Arber et al. Cell 88:393-403, 1997). At this time, this was the first genetically altered animal model to develop this devastating disease. Interestingly, MLP was also found to be downregulated in humans with heart failure (Zolk et al. Circulation 101:2674-2677, 2000) and MLP mutations are able to cause hypertrophic and dilated forms of cardiomyopathy in humans (Bos et al. Mol Genet Metab 88:78-85, 2006; Geier et al. Circulation 107:1390-1395, 2003; Hershberger et al. Clin Transl Sci 1:21-26, 2008; Knöll et al. Cell 111:943-955, 2002; Knöll et al. Circ Res 106:695704, 2010; Mohapatra et al. Mol Genet Metab 80:207-215, 2003). Although considerable efforts have been undertaken to unravel the underlying molecular mechanisms - how MLP mutations, either in model organisms or in the human setting cause these diseases are still unclear. In contrast, only precise knowledge of the underlying molecular mechanisms will allow the development of novel and innovative therapeutic strategies to combat this otherwise
\end{abstract}

B. Buyandelger $\cdot$ K.-E. Ng $\cdot$ S. Miocic $\cdot$ I. Piotrowska

S. Gunkel $\cdot$ C.-H. Ku $\cdot$ R. Knöll $(\bowtie)$

Myocardial Genetics,

British Heart Foundation-Centre for Research Excellence,

National Heart \& Lung Institute, Imperial College,

South Kensington Campus, Flowers Building, 4th floor,

London SW7 2AZ, UK

e-mail: r.knoell@imperial.ac.uk lethal condition. The focus of this review will be on the function of MLP in cardiac mechanosensation and we shall point to possible future directions in MLP research.

Keywords Muscle stretch - Mechanoreceptor .

Mechanosensitivity - Gene expression · Cardiac function .

Cardiac muscle $\cdot$ Cardiac myocytes · Cardiac sarcomere .

Cardiomyocyte $\cdot$ Cardiovascular control

$\begin{array}{ll}\text { Abbreviations } \\ \text { ALP } & \text { Actinin associated LIM protein } \\ \text { BNP } & \text { Brain natriuretic peptide } \\ \text { DCM } & \text { Dilated cardiomyopathy } \\ \text { HDAC4 } & \text { Histone deacetylases } \\ \text { HCM } & \text { Hypertrophic cardiomyopathy } \\ \text { MLP } & \text { Muscle LIM protein } \\ \text { NLS } & \text { Nuclear translocation } \\ \text { PE } & \text { Phenylephrine } \\ \text { PLN } & \text { Phospholamban } \\ \text { PKC } & \text { Protein kinase C } \\ \text { SERCA } & \text { Sarcoplasmic reticulum calcium ATPase } \\ \text { TCAP } & \text { Telethonin }\end{array}$

\section{Introduction}

Muscle LIM protein (MLP) mutations can cause, either in humans or transgenic animals, severe forms of cardiomyopathy and associated heart failure, but the underlying molecular mechanisms remain poorly understood. In this regard, MLP has been associated with a wide variety of different biological processes such as cardiac and skeletal myogenesis including cellular differentiation [3], blood vessel remodeling [52], actin depolymerization [43], cyto- 
skeletal stability and regulation of contractility [4], calcium sensitivity [17], as well as mechanosensation [26, 27].

As diverse as its multiple functions are its different localizations. The presence of MLP is not confined to a single compartment; the protein can also be found at the sarcomeric Z-disc/I-band regions of cardiac muscle in different species such as drosophila [39], mouse [4, 6, 17, 21, 27], and humans [26]. In addition, MLP is also located at the costamere (where $\beta 1$-spectrin and zyxin interact with MLP) [14], intercalated disc (where N-RAP interacts with MLP) [13], M-band [14, 27] and the cytoplasm (where MLP interacts with F-actin) [3] as well as the nucleus [2, 3, $6,12,27]$ (Table 1).

The Z-disc is regarded as one of the most complex macromolecular structures in biology [56] and the localization of MLP at this structure has drawn considerable attention. The majority of Z-disc constituents have undoubtedly important structural functions but a variety of observations, such as the translocation of Z-disc proteins to the nucleus and probably to the M-band and other cellular compartments, their interaction with additional signaling molecules such as protein kinase $\mathrm{C}$ (PKC) [32, 54], the prohypertrophic phosphatase calcineurin $[20,21,24]$ and in particular, the observation that MLP at the Z-disc is necessary for calcineurin activation in cardiac myocytes [20, 21, 24] suggest additional previously unexpected features, linking this structure to important intra- and intercellular signal transduction pathways [33]. These features may be achieved by the ability of Z-disc proteins to facilitate macromolecular protein complexes via certain protein / protein interacting modules such as LIM and/or PDZ domains. Furthermore, it was also recently shown that
MLP co-localizes and interacts at the sarcomeric Z-disc with histone deacetylases (HDAC4) and acetylases (PCAF) which can affect and perturb calcium sensitivity, thus highlighting a potential and novel role/function for this multifunctional Z-disc protein.

\section{MLP and mechanosensation}

We initially cloned the MLP cDNA when we applied differential display techniques to identify changes in gene expression following brief periods of myocardial ischemia [29]. Since our initial observation, MLP's stress inducibility has been confirmed by a variety of different groups using different in vivo and in vitro experimental settings such as lengthening and shortening contractions [31], mechanical stimulation after Botulinum neurotoxin-A injection [51], fatiguing jumping exercise [35], as well as stretch of smooth muscle cells [9].

It was also demonstrated that overexpression of $\beta$ receptor kinase 1 inhibitor in the MLP-deficient background resulted in the prevention of heart failure [46]. In another approach, also related to an intervention in $\beta$ receptor mediated signaling, phospholamban (PLN) was ablated in $\mathrm{MLP}^{-/-}$animals and, similar to the previous study, a complete rescue effect was observed [41]. The stunning improvement of function in these double transgenic mouse models is not solely due to improved calcium metabolism because MLP-deficient animals exhibit normal or enhanced sacroplasmic reticulum calcium ATPase (SERCA) function [50] and PLN phosphorylation was also found to be significantly increased in $\mathrm{MLP}^{-1-}$ animals [1],

Table 1 MLP (CRP3, CSRP3) interacting proteins

\begin{tabular}{|c|c|c|c|}
\hline Protein name & Localization & Situation where interaction was studied & Reference \\
\hline Alpha actinin & Z-disc & Avian smooth muscle & Louis et al. [37] \\
\hline Telethonin (TCAP) & Z-disc & Cardiac muscle & Knöll et al. [26] \\
\hline Cofilin 2 & Z-disc & Cardiac and skeletal muscles & Papalouka et al. [43] \\
\hline HDAC4 & Z-disc, I- and A-band of sarcomere & Papillary muscles and or skinned fibers & Gupta et al. [17] \\
\hline PCAF & Z-disc, I- and A-band of sarcomere & Papillary muscles and/or skinned fibers & Gupta et al. [17] \\
\hline Zyxin & Costamere & In vitro & Louis et al. [37] \\
\hline$\beta 1$ spectrin & Costamere & Cardiac muscle & Flick et al. [14] \\
\hline Integrin linked kinase (ILK) & $\begin{array}{l}\text { Costamere } \\
\text { Z-disc }\end{array}$ & In vitro & Postel et al. [45] \\
\hline N-RAP & Intercalated disc & In vitro & Ehler et al. [13] \\
\hline MyoD & Nucleus & In vitro & Kong et al. [30] \\
\hline MRF4 & Nucleus & In vitro & Kong et al. [30] \\
\hline myogenin & Nucleus & In vitro & Kong et al. [30] \\
\hline F-actin & Cytoplasm & Cell culture $\mathrm{C} 2 \mathrm{C} 12$ & Arber et al. [2] \\
\hline D-Lactate dehydrogenase & Mitochondria & Skeletal muscle & Flick et al. [15] \\
\hline
\end{tabular}

The table lists MLP interacting proteins, their compartmental localization as well the situations where the interactions were studied 
hence these observations suggest that other mechanisms, for example defects in mechanosensation, mechanotransduction, calcium sensitivity, and/or changes in passive myocardial stiffness may account for the rescue effect.

Another important finding is that $\mathrm{MLP}^{-/-}$animals were born in the expected Mendelian frequencies, as such MLP is dismissible during embryonic development but essential for adaptation of the heart to increased hemodynamic demands after birth, where MLP-deficient animals begin to develop heart failure and, depending on the genetic background, develop also significant lethality. In this regard, $\mathrm{MLP}^{-/}$-isolated cardiomyocytes are defective upon mechanical stimulation in brain natriuretic peptide (BNP) induction, which is an important indicator of cell stretch, whereas endothelin 1 or phenylephrine (PE) were still able to induce BNP expression in these cells [26], pointing to a potential role of MLP further upstream in the signal transduction cascade. A similar defect in BNP gene expression following stretch in an in vitro cell culture system has also been obtained when the W4R-MLP mutation, observed in human individuals affected by cardiomyopathy and heart failure, has been analyzed in a knock-in mouse model [27] or when MLP mediated nuclear translocation was inhibited by the use of a synthetic nuclear localization signal (NLS) peptide in neonatal rat cardiomyocytes stretched for $48 \mathrm{~h}$ at $1 \mathrm{~Hz}$ and $10 \%$ maximal strain [7] or under in vivo conditions in MLP heterozygous animals after myocardial infarction [21].

MLP has multiple binding targets and is also able to bind to telethonin (TCAP), a 167 amino-acids protein known to interact with the amino terminal titin at the sarcomeric Zdisc [56]. In this regard, we observed loss of telethonin at the Z-disc in a subset of $\mathrm{MLP}^{-/-}$cardiomyocytes as well as in myocardial biopsies from patients carrying the W4RMLP mutation, which is supported by our finding that W4R-MLP binds with less affinity to telethonin [26, 27]. Interestingly, this Z-disc defect is also completely rescued in the MLP/PLN double knockout animals supported by electron microscopy and immuno-histochemistry analysis [26]. Although loss of telethonin at the sarcomeric Z-disc is a specific effect and was not observed after myocardial infarction or in other Z-disc protein knockout models such as the actinin associated LIM protein (ALP) knockout mouse [44], it should be noted that loss of telethonin in a subset of myofibers in neurogenic disorders has been observed as well [48], as such there is a possibility that additional factors and/or pathologies might provoke loss or translocation of telethonin.

Another important aspect was the significant defect in passive elasticity under MLP deficiency, which is probably responsible for the diastolic dysfunction observed in these animals before they develop global heart failure. This defect is well documented, either in isolated papillary muscles [26] or whole hearts from 2-week-old MLPdeficient animals [36]. Moreover, although adult MLP deficient animals have a stiffer stress-strain relationship, chamber compliance increased as a function of dilatation, which suggests that systolic function in the MLP knockout animals may temporarily improve as a result of alterations in chamber compliance, which is mediated by dilation. In other words, a balance may exist between exploiting the Frank-Starling mechanism and altering chamber compliance that maintains function in the absence of hypertrophic growth. This mechanism may initially be compensatory but may, over time, result in maladaptation [11]. Interestingly, a defect in muscle stiffness (rigidity which can affect excitation-contraction coupling) has also been observed in the W4R-MLP knock in animals and which suggests a direct functional link of MLP, possibly via telethonin, to titin $[26,27,36]$. It remains to be elucidated whether changes in skeletal muscle passive elasticity are associated with adaptive or maladaptive events. The underlying molecular mechanisms remain unclear, changes in titin isoform gene expression as well as changes in titin posttranslational modifications or of other known or even unknown genes may account for the observed effects. It will be interesting to analyze, in addition, whether the sarcomeric Z-disc itself affects passive stiffness. However, given the presence of MLP in the cytoplasm - and possibly its direct interaction with I-band titin-MLP might well have direct but so far not well-studied effects on titin's passive elasticity.

Based on these observations, it was suggested that the primary defect in MLP deficient animals is not located in the downstream pathway for gene induction but rather in the initial sensing process of the stretch stimulus. Thus, MLP was suggested to be part of a macromolecular cardiac mechanical stretch sensor.

Besides its Z-disc location, MLP has also been observed at the costameres (focal adhesions), the areas where force generating sarcomeres are coupled with the sarcolemma [25], and where MLP might be able to interact with its aminoterminal LIM1 domain to $\beta 1$ spectrin and with its carboxyterminal LIM2 domain to $\alpha$ actinin [14]. Hence, MLP would be perfectly suited there, in addition to its Zdisc localization, to serve as a mechanosensor and/or to perform similar functions like zyxin. Zyxin is also a LIM protein, located at focal adhesions, known to interact with MLP (Table 1, Fig. 1) and able to function as a mechanotransducer and transcription factor-at least in endothelial cells (Table 1, Fig. 1) [37, 53].

MLP contains several potential phosphorylation sites and might, at the costamere as well as at the Z-disc region, probably also interact with integrin linked kinase (ILK) $[28,45]$, an integrin-binding protein with important functions in mechanosensation, particularly in fibroblasts 


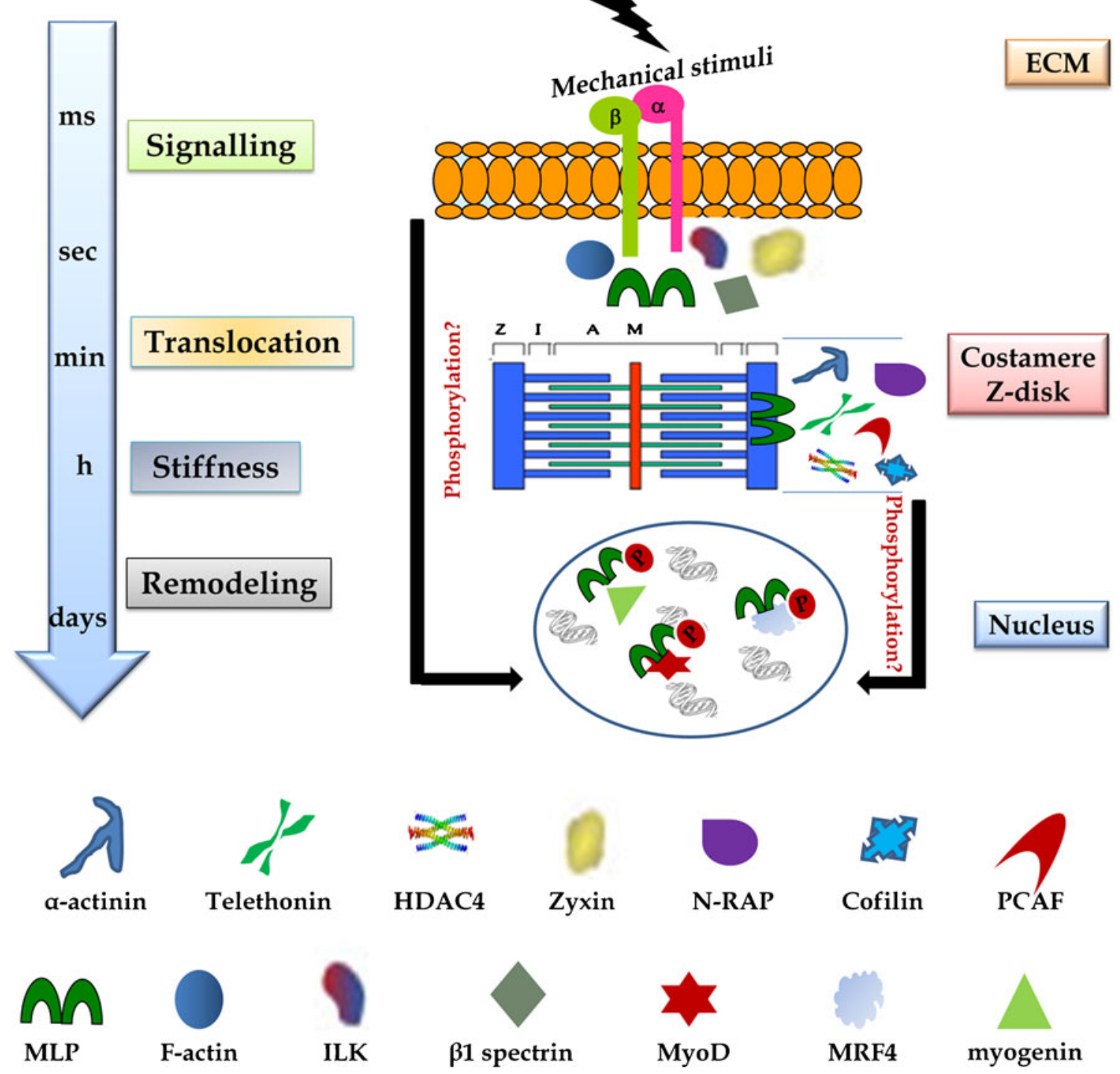

Fig. 1 Schematic diagram of MLP shuttling between compartments. This is an over-simplified diagram depicting the location of MLP at the costameres, Z-discs as well in the nucleus. The left side indicates

[38]. Besides this interaction, MLP may also be able to interact with a variety of other factors present at the costameres such as integrins, focal adhesion kinase, and Src kinase. Src kinase, similar to ILK, also has been shown to have an essential role in mechanosensation by phosphorylating p130Cas [19, 47], however, at present, the link between MLP and its ability to interact with ILK and/or Src kinase is less understood and has not been investigated in detail.

MLP is probably present in two different molecular forms [6]: Firstly, the oligomeric form, which is present at the sarcolemma and the cytoskeleton and the monomeric form, which was found exclusively in the nucleus. Interestingly, after myocardial infarction and pressure overload in animals and in failing human hearts, nuclear as well a possible timescale after a stimulus. $m s$ milliseconds, sec seconds, min minutes, $h$ hours; $\alpha, \beta$ ntegrins

MLP levels in the myocardium increased at the expense of non-nuclear MLP. In failing human hearts, almost no MLP was detectable outside the nucleus. Evidence for nucleocytoplasmic shuttling of MLP on the basis of its nuclear NLS was also provided [7]. Here the authors used cellpermeable synthetic peptides containing the nuclear localization signal (RKYGPG) of MLP and were able to inhibit any further shuttling of this protein, thus clearly documenting functionality of this NLS. In addition, inhibition of nuclear translocation prevented the increased protein accumulation usually seen under phenylephrine treatment of isolated cardiomyocytes, indicating a vital role of MLP in the control of hypertrophy after agonist stimulation. Interestingly, cyclic strain of myocytes after prior NLS treatment resulted in disarrayed sarcomeres, an important 
observation that can probably be compared to the in vivo situation [4].

MLP does not contain a DNA-binding domain and thus cannot directly bind DNA, but might be able to bind to and affect important cardiac transcription factors such as GATA4, GATA6, AP1 or serum response factor (SRF). It has in fact been shown previously, that CSRP2, which is closely related to MLP (CSRP3), can bind GATAs and SRF and synergistically enhance gene expression in smooth muscle cells [10]. By linking different transcription factor complexes, LIM proteins of the CSRP family may integrate the activities of multiple nuclear regulatory proteins to coordinate gene-expression. MLP may also facilitate nucleo-cytoplasmic shuttling of its non-nuclear target calcineurin, which has been demonstrated to translocate to the nucleus in hypertrophied cardiac myocytes [18]. In this context it was recently shown, that MLP was the most differentially expressed transcriptional regulator when two different animal crosses (i.e. Piedmontese myostatin mutants $\times$ Hereford versus Wagyu $\times$ Hereford) were analyzed, pointing to a potential role of MLP in the inhibition of muscle growth and thus (possibly) to a protective function of MLP [23].

Because MLP can be found in the nucleus following biomechanical stress in vivo as well as in vitro $[6,7,12]$ and because MLP mutations have effects on its Z-disc and nuclear localization [27] it might well be of interest to analyze precisely which MLP pool shuttles into the nucleus and whether all of these different MLP pools are able to exchange information with the nuclear or other compartments. Further investigations on posttranslational modification such as phosphorylation, sumoylation, or acetylation and their potential effects on nuclear or any other translocation and which kinases and/or phosphatases are at play would provide further insight on the diverse roles of MLP.

For example, MLP is acetylated within its NLS on position K69 [17], a modification thought to affect calcium sensitivity and which might potentially be able to affect MLP's nuclear-cytoplasmic shuttling. As such, it might be important to examine the effects of human mutations on nuclear or any other localization and to analyze their ability to activate a specific gene program. In particular, the K69RMLP mutation, found in an individual affected by DCM and endocardial fibroelastosis [42] might well have effects on both: calcium sensitivity and nuclear translocation.

Of equal importance is probably the observation that loss of MLP is associated with a severe spontaneous cardiac phenotype but only very mild skeletal muscle abnormality [5] - similar observations also have been made in the W4RMLP knock in animals [27]. Nevertheless, it might be important to examine whether MLP mutations are as well associated with muscular dystrophy in patients. Analyzing which pathways are activated in skeletal muscle to prevent the onset of severe muscle disease in the MLP deficient animals might also be a possible step towards a better understanding of the diverse functions of MLP. Although important pioneering studies on MLP in smooth muscle cells have been performed $[9,52]$, the role of MLP in the vasculature remains enigmatic. Last but not least, MLP might also be linked more directly to $\beta$-adrenergic signaling, but this link has also not been analyzed in detail.

\section{Summary and conclusions}

The heart and particular cardiomyocytes are dynamic structures, contracting and relaxing on a constant basis. As such, they have to respond quickly and continuously to hemodynamic and environmental changes but the underlying molecular mechanisms which lead to a "form of constant self re-newal" remain poorly defined, particularly because the heart has developed several different strategies to cope with the problem of mechanosensation and mechanotransduction.

Therefore, it is not too surprising that since our initial description of the involvement of MLP in cardiac mechanosensation, additional intra-sarcomeric mechanosensitive signal transduction pathways have been described. Titin contains specific elastic domains within its I-band region (such as the N2B, PEVK and Ig domains) and proteins such as FHL1 [49] or muscle ankyrin repeat proteins such as CARP [40] might be able to bind to these domains and as such participate in constituting a sarcomeric length sensor. Heart failure is quite often associated with increased fibrosis and hence an increase in cell/muscle stiffness which can be counterbalanced by changes in titinmediated intracellular passive elasticity and MLP might well be in a position to transmit information from the costamere to the Z-disc and/or directly to titin as well as into the nucleus. In addition to this, titin contains at its M-band region another mechanosensitive element, its kinase domain which interacts with the zinc finger protein nbr1, with p62 and MuRF 2, a RING-B-box E3 ligase which translocates into the nucleus upon mechanical inactivity [34].

In this regard, MLP is a small but multifunctional protein and localized in different cellular compartments. MLP can be post translationally modified and may well be able to fulfill multiple important functions in parallel. Available evidence from several independent groups supports a function of MLP as part of a macromolecular mechanosensitive signalosome and for a role of MLP as a signal transducer.

MLP may be able to influence cardiac mechanosensation via its location at the sarcomeric Z-disc, where it 
may serve as a tension sensor or via its location at the costameres (focal adhesions) where it may respond rapidly to changes in muscle length caused by cell/ extracellular matrix interactions. However, the precise role and mechanism of MLP in these processes still remains elusive (please see Fig. 1).

In this regard, the identification of novel MLPinteracting proteins might provide new insights into MLP function. Although the translocation of MLP into the nucleus is well studied, its function in the nucleus is not completely understood. MLP almost certainly undergoes posttranslational modifications but our knowledge here remains also limited. As pointed out earlier, MLP is associated with changes in cardiac or skeletal passive stiffness-again the underlying molecular events remain poorly defined. It is also unclear as to why MLP deficiency is associated with a severe cardiomyopathy phenotype but only mild skeletal muscle pathology. Another interesting feature is the effect of MLP on calcium sensitivity, which remains also unclear.

In conclusion, MLP might have different functions and one possible scenario might be that this molecule serves as part of one or even several different mechanosensitive macromolecular signalosomes. One of these complexes might be located at the costameres, where this protein interacts with ILK, zyxin, $\beta 1$ spectrin and $\alpha$ actinin and might be involved in length sensation. Another complex might be located at the sarcomeric Z-disc, where MLP might be involved in the sensation of tension.

Open Access This article is distributed under the terms of the Creative Commons Attribution Noncommercial License which permits any noncommercial use, distribution, and reproduction in any medium, provided the original author(s) and source are credited.

\section{References}

1. Antoons G, Vangheluwe P, Volders PG, Bito V, Holemans P, Ceci M, Wuytack F, Caroni P, Mubagwa K, Sipido KR (2006) Increased phospholamban phosphorylation limits the forcefrequency response in the $\mathrm{MLP}^{-/-}$mouse with heart failure. $\mathrm{J}$ Mol Cell Cardiol 40:350-360

2. Arber S, Caroni P (1996) Specificity of single LIM motifs in targeting and LIM/LIM interactions in situ. Genes Dev 10:289300

3. Arber S, Halder G, Caroni P (1994) Muscle LIM protein, a novel essential regulator of myogenesis, promotes myogenic differentiation. Cell 79:221-231

4. Arber S, Hunter JJ, Ross J Jr, Hongo M, Sansig G, Borg J, Perriard JC, Chien KR, Caroni P (1997) MLP-deficient mice exhibit a disruption of cardiac cytoarchitectural organization, dilated cardiomyopathy, and heart failure. Cell 88:393-403

5. Barash IA, Mathew L, Lahey M, Greaser ML, Lieber RL (2005) Muscle LIM protein plays both structural and functional roles in skeletal muscle. Am J Physiol Cell Physiol 289: C1312-C1320

6. Boateng SY, Belin RJ, Geenen DL, Margulies KB, Martin JL, Hoshijima M, de Tombe PP, Russell B (2007) Cardiac dysfunction and heart failure are associated with abnormalities in the subcellular distribution and amounts of oligomeric muscle LIM protein. Am J Physiol Heart Circ Physiol 292:H259-H2569

7. Boateng SY, Senyo SE, Qi L, Goldspink PH, Russell B (2009) Myocyte remodeling in response to hypertrophic stimuli requires nucleocytoplasmic shuttling of muscle LIM protein. J Mol Cell Cardiol 47:426-435

8. Bos JM, Poley RN, Ny M, Tester DJ, Xu X, Vatta M, Towbin JA, Gersh BJ, Ommen SR, Ackerman MJ (2006) Genotype-phenotype relationships involving hypertrophic cardiomyopathy-associated mutations in titin, muscle LIM protein, and telethonin. Mol Genet Metab 88:78-85

9. Campos LC, Miyakawa AA, Barauna VG, Cardoso L, Borin TF, Dallan LA, Krieger JE (2009) Induction of CRP3/MLP expression during vein arterialization is dependent on stretch rather than shear stress. Cardiovasc Res 83:140-147

10. Chang DF, Belaguli NS, Iyer D, Roberts WB, Wu SP, Dong XR, Marx JG, Moore MS, Beckerle MC, Majesky MW, Schwartz RJ (2003) Cysteine-rich LIM-only proteins CRP1 and CRP2 are potent smooth muscle differentiation cofactors. Dev Cell 4:107118

11. Costandi PN, Frank LR, McCulloch AD, Omens JH (2006) Role of diastolic properties in the transition to failure in a mouse model of the cardiac dilatation. Am J Physiol Heart Circ Physiol 291: H2971-H2979

12. Ecarnot-Laubriet A, De Luca K, Vandroux D, Moisant $M$, Bernard C, Assem M, Rochette L, Teyssier JR (2000) Downregulation and nuclear relocation of MLP during the progression of right ventricular hypertrophy induced by chronic pressure overload. J Mol Cell Cardiol 32:2385-2395

13. Ehler E, Horowits R, Zuppinger C, Price RL, Perriard E, Leu M, Caroni P, Sussman M, Eppenberger HM, Perriard JC (2001) Alterations at the intercalated disk associated with the absence of muscle LIM protein. J Cell Biol 153:7637672

14. Flick MJ, Konieczny SF (2000) The muscle regulatory and structural protein MLP is a cytoskeletal binding partner of betaIspectrin. J Cell Sci 113:1553-1564

15. Flick MJ, Konieczny SF (2002) Identification of putative mammalian D-lactate dehydrogenase enzymes. Biochem Biophys Res Commun 295:910-916

16. Geier C, Perrot A, Ozcelik C, Binner P, Counsell D, Hoffmann K, Pilz B, Martiniak Y, Gehmlich K, van der Ven PF, Furst DO, Vornwald A, von Hodenberg E, Nurnberg P, Scheffold T, Dietz R, Osterziel KJ (2003) Mutations in the human muscle LIM protein gene in families with hypertrophic cardiomyopathy. Circulation 107:1390-1395

17. Gupta MP, Samant SA, Smith SH, Shroff SG (2008) HDAC4 and PCAF bind to cardiac sarcomeres and play a role in regulating myofilament contractile activity. J Biol Chem 283:10135-10146

18. Hallhuber M, Burkard N, Wu R, Buch MH, Engelhardt S, Hein L, Neyses L, Schuh K, Ritter O (2006) Inhibition of nuclear import of calcineurin prevents myocardial hypertrophy. Circ Res 99:626-635

19. Hamasaki K, Mimura T, Morino N, Furuya H, Nakamoto T, Aizawa S, Morimoto C, Yazaki Y, Hirai H, Nojima Y (1996) Src kinase plays an essential role in integrin-mediated tyrosine phosphorylation of Crk-associated substrate p130Cas. Biochem Biophys Res Commun 222:338-343

20. Heineke J, Molkentin JD (2006) Regulation of cardiac hypertrophy by intracellular signalling pathways. Nat Rev Mol Cell Biol 7:589-600

21. Heineke J, Ruetten H, Willenbockel C, Gross SC, Naguib M, Schaefer A, Kempf T, Hilfiker-Kleiner D, Caroni P, Kraft T, 
Kaiser RA, Molkentin JD, Drexler H, Wollert KC (2005) Attenuation of cardiac remodeling after myocardial infarction by muscle LIM protein-calcineurin signaling at the sarcomeric Zdisc. Proc Natl Acad Sci USA 102:1655-1560

22. Hershberger RE, Parks SB, Kushner JD, Li D, Ludwigsen S, Jakobs P, Nauman D, Burgess D, Partain J, Litt M (2008) Coding sequence mutations identified in MYH7, TNNT2, SCN5A, CSRP3, LBD3, and TCAP from 313 patients with familial or idiopathic dilated cardiomyopathy. Clin Transl Sci 1:21-26

23. Hudson NJ, Reverter A, Dalrymple BP (2009) A differential wiring analysis of expression data correctly identifies the gene containing the causal mutation. PLoS Comput Biol 5:e1000382

24. Jeong LS, Tosh DK, Kim HO, Wang T, Hou X, Yun HS, Kwon Y, Lee SK, Choi J, Zhao LX (2008) First synthesis of 4'selenonucleosides showing unusual Southern conformation. Org Lett 10:209-212

25. Kanchanawong P, Shtengel G, Pasapera AM, Ramko EB, Davidson MW, Hess HF, Waterman CM (2010) Nanoscale architecture of integrin-based cell adhesions. Nature 468:580584

26. Knöll R, Hoshijima M, Hoffman HM, Person V, LorenzenSchmidt I, Bang ML, Hayashi T, Shiga N, Yasukawa H, Schaper W, McKenna W, Yokoyama M, Schork NJ, Omens JH, McCulloch AD, Kimura A, Gregorio CC, Poller W, Schaper J, Schultheiss HP, Chien KR (2002) The cardiac mechanical stretch sensor machinery involves a $\mathrm{Z}$ disc complex that is defective in a subset of human dilated cardiomyopathy. Cell 111:943-955

27. Knöll R, Kostin S, Klede S, Savvatis K, Klinge L, Stehle I, Gunkel S, Kotter S, Babicz K, Sohns M, Miocic S, Didie M, Knoll G, Zimmermann WH, Thelen P, Bickeboller H, Maier LS, Schaper W, Schaper J, Kraft T, Tschope C, Linke WA, Chien KR (2010) A common MLP (muscle LIM protein) variant is associated with cardiomyopathy. Circ Res 106:695-704

28. Knöll R, Postel R, Wang J, Kratzner R, Hennecke G, Vacaru AM, Vakeel P, Schubert C, Murthy K, Rana BK, Kube D, Knoll G, Schafer K, Hayashi T, Holm T, Kimura A, Schork N, Toliat MR, Nurnberg P, Schultheiss HP, Schaper W, Schaper J, Bos E, Den Hertog J, van Eeden FJ, Peters PJ, Hasenfuss G, Chien KR, Bakkers J (2007) Laminin-alpha4 and integrin-linked kinase mutations cause human cardiomyopathy via simultaneous defects in cardiomyocytes and endothelial cells. Circulation 116:515-525

29. Knöll R, Zimmermann R, Arras M, Schaper W (1996) Characterization of differentially expressed genes following brief cardiac ischemia. Biochem Biophys Res Commun 221:402-407

30. Kong F, Kudla K (1997) Muscle LIM protein promotes myogenesis by enhancing the activity of MyoD. Mol Cell Biol $17: 4750-4760$

31. Kostek MC, Chen YW, Cuthbertson DJ, Shi R, Fedele MJ, Esser KA, Rennie MJ (2007) Gene expression responses over $24 \mathrm{~h}$ to lengthening and shortening contractions in human muscle: major changes in CSRP3, MUSTN1, SIX1, and FBXO32. Physiol Genomics 31:42-52

32. Kuroda S, Tokunaga C, Kiyohara Y, Higuchi O, Konishi H, Mizuno K, Gill GN, Kikkawa U (1996) Protein-protein interaction of zinc finger LIM domains with protein kinase C. J Biol Chem 271:31029-31032

33. Lange S, Ehler E, Gautel M (2006) From A to Z and back? Multicompartment proteins in the sarcomere. Trends Cell Biol $16: 11-18$

34. Lange S, Xiang F, Yakovenko A, Vihola A, Hackman P, Rostkova E, Kristensen J, Brandmeier B, Franzen G, Hedberg B, Gunnarsson LG, Hughes SM, Marchand S, Sejersen T, Richard I, Edstrom L, Ehler E, Udd B, Gautel M (2005) The kinase domain of titin controls muscle gene expression and protein turnover. Science 308:1599

35. Lehti M, Kivela R, Komi P, Komulainen J, Kainulainen H, Kyrolainen H (2009) Effects of fatiguing jumping exercise on
mRNA expression of titin-complex proteins and calpains. J Appl Physiol 106:1419-1424

36. Lorenzen-Schmidt I, Stuyvers BD, ter Keurs HE, Date MO, Hoshijima M, Chien KR, McCulloch AD, Omens JH (2005) Young MLP deficient mice show diastolic dysfunction before the onset of dilated cardiomyopathy. J Mol Cell Cardiol 39:241-250

37. Louis HA, Pino JD, Schmeichel KL, Pomies P, Beckerle MC (1997) Comparison of three members of the cysteine-rich protein family reveals functional conservation and divergent patterns of gene expression. J Biol Chem 272:27484-27491

38. Maier S, Lutz R, Gelman L, Sarasa-Renedo A, Schenk S, Grashoff C, Chiquet M (2008) Tenascin-C induction by cyclic strain requires integrin-linked kinase. Biochim Biophys Acta 1783:1150-1162

39. Mery A, Taghli-Lamallem O, Clark KA, Beckerle MC, Wu X, Ocorr K, Bodmer R (2008) The Drosophila muscle LIM protein, Mlp84B, is essential for cardiac function. J Exp Biol 211:15-23

40. Miller MK, Bang ML, Witt CC, Labeit D, Trombitas C, Watanabe K, Granzier H, McElhinny AS, Gregorio CC, Labeit S (2003) The muscle ankyrin repeat proteins: CARP, ankrd2/Arpp and DARP as a family of titin filament-based stress response molecules. J Mol Biol 333:951-964

41. Minamisawa S, Hoshijima M, Chu G, Ward CA, Frank K, Gu Y, Martone ME, Wang Y, Ross J Jr, Kranias EG, Giles WR, Chien KR (1999) Chronic phospholamban-sarcoplasmic reticulum calcium ATPase interaction is the critical calcium cycling defect in dilated cardiomyopathy. Cell 99:313-322

42. Mohapatra B, Jimenez S, Lin JH, Bowles KR, Coveler KJ, Marx JG, Chrisco MA, Murphy RT, Lurie PR, Schwartz RJ, Elliott PM, Vatta M, McKenna W, Towbin JA, Bowles NE (2003) Mutations in the muscle LIM protein and alpha-actinin-2 genes in dilated cardiomyopathy and endocardial fibroelastosis. Mol Genet Metab 80:207-215

43. Papalouka V, Arvanitis DA, Vafiadaki E, Mavroidis M, Papadodima SA, Spiliopoulou CA, Kremastinos DT, Kranias EG, Sanoudou D (2009) Muscle LIM protein interacts with cofilin 2 and regulates Factin dynamics in cardiac and skeletal muscle. Mol Cell Biol 29:6046-6058

44. Pashmforoush M, Pomies P, Peterson KL, Kubalak S, Ross J Jr, Hefti A, Aebi U, Beckerle MC, Chien KR (2001) Adult mice deficient in actinin-associated LIM-domain protein reveal a developmental pathway for right ventricular cardiomyopathy. Nat Med 7:591-597

45. Postel R, Vakeel P, Topczewski J, Knoll R, Bakkers J (2008) Zebrafish integrin-linked kinase is required in skeletal muscles for strengthening the integrin-ECM adhesion complex. Dev Biol 318:92-101

46. Rockman H, Chien K, Choi D-J, Iaccarino G, Hunter J, Ross J, Lefkowitz R, Koch W (1998) Expression of a beta adrenergic kinase 1 inhibitor prevents the development of myocardial failure in gene targeted mice. Proc Natl Acad Sci USA 95:7000-7005

47. Sawada Y, Tamada M, Dubin-Thaler BJ, Cherniavskaya O, Sakai R, Tanaka S, Sheetz MP (2006) Force sensing by mechanical extension of the Src family kinase substrate p130Cas. Cell 127:1015-1026

48. Schroder R, Reimann J, Iakovenko A, Mues A, Bonnemann CG, Matten J, Gautel M (2001) Early and selective disappearance of telethonin protein from the sarcomere in neurogenic atrophy. $\mathrm{J}$ Muscle Res Cell Motil 22:259-264

49. Sheikh F, Raskin A, Chu PH, Lange S, Domenighetti AA, Zheng M, Liang X, Zhang T, Yajima T, Gu Y, Dalton ND, Mahata SK, Dorn GW 2nd, Heller-Brown J, Peterson KL, Omens JH, McCulloch AD, Chen J (2008) An FHL1-containing complex within the cardiomyocyte sarcomere mediates hypertrophic 
biomechanical stress responses in mice. J Clin Invest 118:38703880

50. Su Z, Yao A, Zubair I, Sugishita K, Ritter M, Li F, Hunter JJ, Chien KR, Barry WH (2001) Effects of deletion of muscle LIM protein on myocyte function. Am J Physiol Heart Circ Physiol 280:26-73

51. Velders M, Legerlotz K, Falconer SJ, Stott NS, McMahon CD, Smith HK (2008) Effect of botulinum toxin A-induced paralysis and exercise training on mechanosensing and signalling gene expression in juvenile rat gastrocnemius muscle. Exp Physiol 93:1273-1283

52. Wang X, Li Q, Adhikari N, Hall JL (2006) A role for muscle LIM protein (MLP) in vascular remodeling. J Mol Cell Cardiol 40:503-509
53. Wojtowicz A, Babu SS, Li L, Gretz N, Hecker M, Cattaruzza M (2010) Zyxin mediation of stretch-induced gene expression in human endothelial cells. Circ Res 107:898-902

54. Zhou Q, Chu PH, Huang C, Cheng CF, Martone ME, Knoll G, Shelton GD, Evans S, Chen J (2001) Ablation of Cypher, a PDZLIM domain Z-line protein, causes a severe form of congenital myopathy. J Cell Biol 155:605-612

55. Zolk O, Caroni P, Bohm M (2000) Decreased expression of the cardiac LIM domain protein MLP in chronic human heart failure. Circulation 101:2674-2677

56. Zou P, Pinotsis N, Lange S, Song YH, Popov A, Mavridis I, Mayans OM, Gautel M, Wilmanns M (2006) Palindromic assembly of the giant muscle protein titin in the sarcomeric Zdisk. Nature 439:229-233 